University of Nebraska - Lincoln

DigitalCommons@University of Nebraska - Lincoln

John Janovy Publications

Papers in the Biological Sciences

10-2001

\title{
Physid Snails as Sentinels of Freshwater Nematomorphs
}

\author{
Ben Hanelt \\ University of New Mexico - Gallup Campus, bhanelt@unm.edu \\ L. E. Grother \\ University of Nebraska - Lincoln \\ John J. Janovy Jr. \\ University of Nebraska - Lincoln, jjanovy1@unl.edu
}

Follow this and additional works at: https://digitalcommons.unl.edu/bioscijanovy

Part of the Parasitology Commons

Hanelt, Ben; Grother, L. E.; and Janovy, John J. Jr., "Physid Snails as Sentinels of Freshwater Nematomorphs" (2001). John Janovy Publications. 25.

https://digitalcommons.unl.edu/bioscijanovy/25

This Article is brought to you for free and open access by the Papers in the Biological Sciences at DigitalCommons@University of Nebraska - Lincoln. It has been accepted for inclusion in John Janovy Publications by an authorized administrator of DigitalCommons@University of Nebraska - Lincoln. 


\title{
PHYSID SNAILS AS SENTINELS OF FRESHWATER NEMATOMORPHS
}

\author{
B. Hanelt, L. E. Grother, and J. Janovy, Jr. \\ School of Biological Sciences, University of Nebraska-Lincoln, Lincoln, Nebraska 68588-0118
}

\begin{abstract}
Freshwater nematomorphs, or gordiids, are parasitic as larvae, but free-living in aquatic environments as adults. Studies based on the collection of adults have reported gordiids to be widespread, but discontinuous in distribution. However, a relatively short adult life span and unknown life history make the detection of adults difficult. An alternative approach to investigate gordiid distribution is to use cysts. Of all paratenic hosts, snails were chosen because they lacked internal defense reactions to the cysts and become easily infected. Here, it is reported that the occurrence of gordiids on the basis of the cyst stage is much more common than previously reported, thus altering the perception of how common these worms are. Using this modified survey procedure, gordiid cysts were found at $70 \%$ of sites examined, in an area where extensive sampling over $3 \mathrm{yr}$ yielded adults only at a single site. Of 1,000 snails dissected, 395 were infected with gordiids (intensity range: 1-465). Furthermore, different types of human-modified landscapes did not affect gordiid distribution, suggesting that as urban and suburban areas sprawl, human encounters or pseudoparasitism with nematomorphs may increase. The results of this study indicate that use of organismal-specific sampling techniques can be critical in studies of parasite distribution and biodiversity.
\end{abstract}

Scientifically, the Nematomorpha has been largely overlooked (Schmidt-Rhaesa, 1997). The gordiid (Nematomorpha: Gordioidea), or hairworm, life cycle involves 4 phases: a freeliving, aquatic adult and larva, a parasitic cyst, and a parasitic larval stage. Free-living adults produce eggs, which hatch into larvae. Larvae penetrate and encyst within aquatic vertebrate and invertebrate hosts (von Linstow, 1883; Dorier, 1930; Inoue, 1960). Insects, usually orthopterans or coleopterans, are infected upon consumption of cysts (Hanelt and Janovy, 1999). Within the insect's gut, larvae excyst and penetrate into the hemocoel (Inoue, 1962), within which the parasites attain full adult size before returning to the free-living stage. Humans may encounter this parasite frequently by finding a worm in the toilet after killing and disposing of a host, usually a cricket (Herter and Neese, 1989). Gordiids have also been reported as pseudoparasites of humans (Stiles, 1907; Hall, 1912; Kagei, 1977), cats (Moisan et al., 1996), and dogs (Horton, 1986). In many of these cases, infection was attributable to the ingestion of adult worms.

To date, the extent to which gordiids are distributed geographically has been investigated only by using adults as indicators. The first study reported 4 species at 49 sites within the British Isles (on the basis of $30 \mathrm{yr}$ of data; Baylis, 1927). More recently, 2 studies in the United States have reported 4 species from 11 sites in Tennessee (18 yr of data; Chandler, 1985), and 3 species from 13 sites in Wisconsin (69 yr of data; Watermolen and Haen, 1994). However, using adults as indicators for the geographic distribution of gordiids is problematic. A short life span, hiding behavior during mating, and variable life cycles depending upon species of host and parasite make adults difficult to detect. Thus, the use of adults as indicators of gordiids can lead to severe underestimations of their numbers and geographic distribution.

An alternative method to investigating whether gordiids occur at a particular location is to look for the presence of cysts. The benefits of this approach are that cysts are long-lived and are found in a variety of host organisms. Thus, with the use of the correct indicator host, it will be possible to collect and quantify cysts year-round without the dependence on the presence of the adult stages. As a host and thus, as an indicator species of gordiids, the common freshwater pulmonate snail Physa gyr-

Received 17 January 2001; revised 20 March 2001; accepted 26 April 2001. ina was used. Although involvement of aquatic snails in the gordiid life cycle in nature is unknown, this species was used because of its wide distribution and its capacity to host cysts (von Linstow, 1883; Chitwood and Chitwood, 1937). Furthermore, $P$. gyrina was examined for the presence of internal defense reactions against cysts, because a good indicator species should not be able to destroy parasites. The strategic placement of sites and the biology of $P$. gyrina snails will allow for the detection of sites at or near which gordiids have recently mated, not simply the dispersal of their eggs or cysts.

Thus, the present study aims to use a novel sampling method to map the distribution of gordiids in a geographically defined area. Furthermore, the effect of human density in different types of human-modified landscapes was tested on the distribution of gordiids.

\section{MATERIALS AND METHODS}

Between September 1999 and May 2000, 20 snails from each of 50 sites were examined. All collection localities were within Lancaster County, Nebraska (Table I), a predominantly agricultural area consisting of rolling loess hills. Adults were only found at a single site (site 1) during extensive sampling in the study area between 1997 and 2000. Sites were chosen to be first- or second-order streams in urban, suburban, and rural areas. To assure independent sample localities, no sites were located directly up- or downstream from each other and all were separated from others by a minimum of $1.5 \mathrm{~km}$. Global positioning system (GPS) readings were recorded for each site, to the nearest 0.01 decimal degrees.

Only snails smaller than $12 \mathrm{~mm}$ were included in this study, because larger snails were harder to flatten and cysts might subsequently have been missed. This method allowed an estimated $100 \%$ rate of detection. Snails were collected by dip net and returned live to the laboratory.

Before dissection, the height of each snail was measured to the nearest $0.1 \mathrm{~mm}$. All dissections were usually completed within 1-2 days of collection. The shell of each snail was removed under a dissecting microscope and the soft tissue was flattened between a glass slide and a coverslip. The status and degree of infection were determined by scanning for cysts at $\times 100$ magnification under a compound microscope. Snails from 2 sites were deposited in the Harold W. Manter Laboratory (HWML) collection, University of Nebraska-Lincoln (site 1: HWML 16128; site 37: HWML 16129).

It was noted that snails exposed to larvae during the gordiids' mating season (late summer through fall) maintained cysts through the late spring. To further investigate the host-parasite interactions, but especially to look for the presence of internal defense system (IDS) reaction, histological preparations were made of snails. Snails collected during the late spring 2000 were fixed in AFA (6\% formalin, $47.5 \%$ ethyl alcohol, 4\% glacial acetic acid, $42.5 \%$ distilled water). Tissues were dehydrated, placed in xylene, and embedded in paraplast using standard 
TABLE I. Site location and infection rates of Physa gyrina with gordiid cysts.

\begin{tabular}{|c|c|c|c|c|}
\hline $\begin{array}{c}\text { Site } \\
\text { number }\end{array}$ & Latitude & Longitude & Prevalance & $\begin{array}{c}\text { Mean } \\
\text { intensity }\end{array}$ \\
\hline 1 & $40^{\circ} 53.15^{\prime}$ & $96^{\circ} 50.08^{\prime}$ & 0.85 & 8.2 \\
\hline 2 & $40^{\circ} 59.21^{\prime}$ & $96^{\circ} 45.50^{\prime}$ & 0.05 & 1.0 \\
\hline 3 & $40^{\circ} 50.59^{\prime}$ & $96^{\circ} 42.71^{\prime}$ & 0.85 & 11.7 \\
\hline 4 & $40^{\circ} 57.55^{\prime}$ & $96^{\circ} 52.72^{\prime}$ & & \\
\hline 5 & $40^{\circ} 55.81^{\prime}$ & $96^{\circ} 51.27^{\prime}$ & 0.2 & 3.8 \\
\hline 6 & $40^{\circ} 47.51^{\prime}$ & $96^{\circ} 40.07^{\prime}$ & & \\
\hline 7 & $40^{\circ} 59.22^{\prime}$ & $96^{\circ} 38.95^{\prime}$ & & \\
\hline 8 & $40^{\circ} 59.00^{\prime}$ & $96^{\circ} 40.90^{\prime}$ & 0.55 & 3.2 \\
\hline 9 & $40^{\circ} 42.83^{\prime}$ & $96^{\circ} 47.18^{\prime}$ & & \\
\hline 10 & $40^{\circ} 41.57^{\prime}$ & $96^{\circ} 51.12^{\prime}$ & & \\
\hline 11 & $40^{\circ} 56.65^{\prime}$ & $96^{\circ} 39.48^{\prime}$ & 0.3 & 1.7 \\
\hline 12 & $40^{\circ} 57.20^{\prime}$ & $96^{\circ} 37.49^{\prime}$ & 0.9 & 10.3 \\
\hline 13 & $40^{\circ} 33.12^{\prime}$ & $96^{\circ} 29.08^{\prime}$ & 1 & 24.9 \\
\hline 14 & $40^{\circ} 35.75^{\prime}$ & $96^{\circ} 31.08^{\prime}$ & 0.6 & 6.0 \\
\hline 15 & $40^{\circ} 37.69^{\prime}$ & $96^{\circ} 31.27^{\prime}$ & 0.85 & 35.1 \\
\hline 16 & $40^{\circ} 38.35^{\prime}$ & $96^{\circ} 29.96^{\prime}$ & 0.75 & 3.2 \\
\hline 17 & $40^{\circ} 31.38^{\prime}$ & $96^{\circ} 49.33^{\prime}$ & 0.25 & 39.4 \\
\hline 18 & $40^{\circ} 31.42^{\prime}$ & $96^{\circ} 54.23^{\prime}$ & 0.1 & 1.0 \\
\hline 19 & $40^{\circ} 35.06^{\prime}$ & $96^{\circ} 45.70^{\prime}$ & 0.3 & 2.2 \\
\hline 20 & $40^{\circ} 36.62^{\prime}$ & $96^{\circ} 42.02^{\prime}$ & 0.25 & 1.0 \\
\hline 21 & $40^{\circ} 43.48^{\prime}$ & $96^{\circ} 33.53^{\prime}$ & 0.6 & 2.2 \\
\hline 22 & $40^{\circ} 46.18^{\prime}$ & $96^{\circ} 28.53^{\prime}$ & 0.95 & 57.9 \\
\hline 23 & $40^{\circ} 35.74^{\prime}$ & $96^{\circ} 51.11^{\prime}$ & & \\
\hline 24 & $40^{\circ} 41.84^{\prime}$ & $96^{\circ} 31.26^{\prime}$ & & \\
\hline 25 & $40^{\circ} 40.44^{\prime}$ & $96^{\circ} 39.50^{\prime}$ & & \\
\hline 26 & $40^{\circ} 50.32^{\prime}$ & $96^{\circ} 32.43^{\prime}$ & & \\
\hline 27 & $40^{\circ} 54.93^{\prime}$ & $96^{\circ} 43.85^{\prime}$ & 0.85 & 2.4 \\
\hline 28 & $40^{\circ} 51.83^{\prime}$ & $96^{\circ} 30.13^{\prime}$ & 1 & 115.2 \\
\hline 29 & $40^{\circ} 53.15^{\prime}$ & $96^{\circ} 31.37^{\prime}$ & 1 & 37.0 \\
\hline 30 & $40^{\circ} 54.92^{\prime}$ & $96^{\circ} 39.97^{\prime}$ & & \\
\hline 31 & $40^{\circ} 40.11^{\prime}$ & $96^{\circ} 44.88^{\prime}$ & 0.1 & 1.0 \\
\hline 32 & $40^{\circ} 38.36^{\prime}$ & $96^{\circ} 50.32^{\prime}$ & & \\
\hline 33 & $40^{\circ} 52.83^{\prime}$ & $96^{\circ} 54.65^{\prime}$ & 0.35 & 2.3 \\
\hline 34 & $40^{\circ} 53.13^{\prime}$ & $96^{\circ} 34.14^{\prime}$ & 0.7 & 7.4 \\
\hline 35 & $40^{\circ} 47.09^{\prime}$ & $96^{\circ} 50.23^{\prime}$ & 0.3 & 1.3 \\
\hline 36 & $40^{\circ} 40.78^{\prime}$ & $96^{\circ} 33.52^{\prime}$ & 0.6 & 2.2 \\
\hline 37 & $40^{\circ} 59.62^{\prime}$ & $96^{\circ} 33.95^{\prime}$ & 1 & 39.8 \\
\hline 38 & $40^{\circ} 43.89^{\prime}$ & $96^{\circ} 37.58^{\prime}$ & 0.15 & 6.7 \\
\hline 39 & $40^{\circ} 57.61^{\prime}$ & $96^{\circ} 34.04^{\prime}$ & 0.65 & 1.8 \\
\hline 40 & $40^{\circ} 39.26^{\prime}$ & $96^{\circ} 35.61^{\prime}$ & 0.75 & 9.5 \\
\hline 41 & $40^{\circ} 39.18^{\prime}$ & $96^{\circ} 27.83^{\prime}$ & 0.4 & 1.4 \\
\hline 42 & $41^{\circ} 1.84^{\prime}$ & $96^{\circ} 29.25^{\prime}$ & 0.95 & 32.5 \\
\hline 43 & $41^{\circ} 2.70^{\prime}$ & $96^{\circ} 37.25^{\prime}$ & & \\
\hline 44 & $41^{\circ} 1.02^{\prime}$ & $96^{\circ} 40.90^{\prime}$ & 0.45 & 2.8 \\
\hline 45 & $41^{\circ} 1.06^{\prime}$ & $96^{\circ} 51.95^{\prime}$ & & \\
\hline 46 & $40^{\circ} 59.82^{\prime}$ & $96^{\circ} 27.85^{\prime}$ & 0.6 & 3.6 \\
\hline 47 & $40^{\circ} 45.23^{\prime}$ & $96^{\circ} 54.66^{\prime}$ & 0.45 & 1.9 \\
\hline 48 & $40^{\circ} 32.29^{\prime}$ & $96^{\circ} 37.85^{\prime}$ & & \\
\hline 49 & $40^{\circ} 31.43^{\prime}$ & $96^{\circ} 33.29^{\prime}$ & & \\
\hline 50 & $40^{\circ} 43.28^{\prime}$ & $96^{\circ} 44.40^{\prime}$ & 0.1 & 1.0 \\
\hline
\end{tabular}

histological techniques. Sections were cut to a thickness of $12 \mu \mathrm{m}$ and stained using hematoxylin and eosin (Pritchard and Kruse, 1982).

The number of cysts per snail and snail height were not normally distributed. These data could not be normalized using transformations and therefore nonparametric statistics were used to analyze these data. Geographical information systems (GIS) data were compiled by use of ArcView (v. 3.2) using population data from the Environmental Systems Research Institute (Redlands, California) and land-use data from the

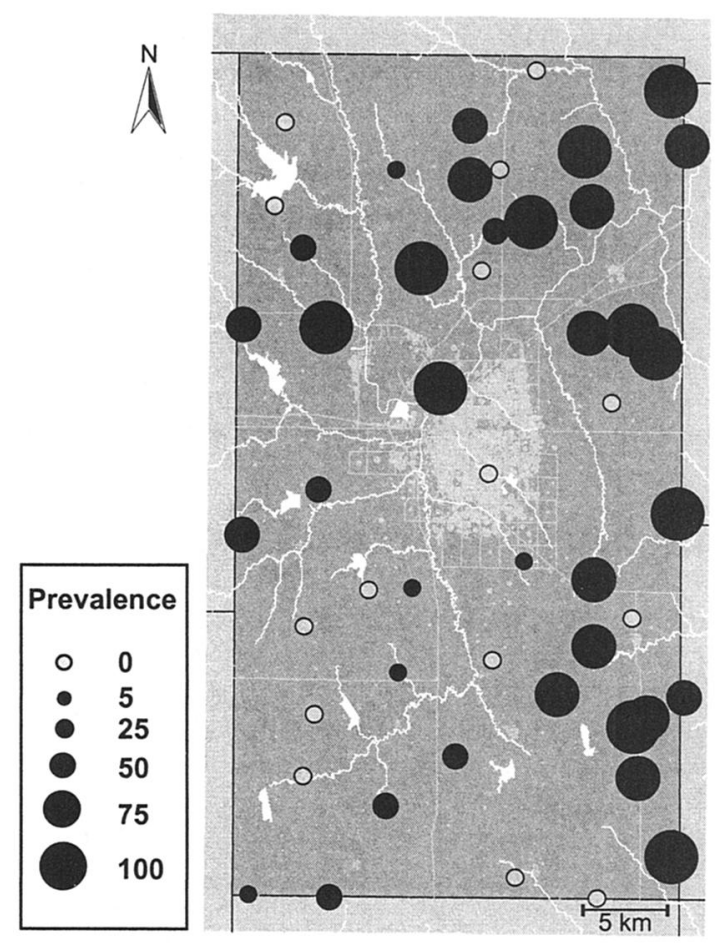

FIGURE 1. Location of sampling sites in Lancaster County (dark gray), Nebraska. Sites testing negative for cysts indicated in open circles, positive in closed circles. Size of circle indicates degree of prevalence. Human population density within the study area indicated in light gray. The city of Lincoln is in the center of the figure. Rivers (lines) and lakes (polygons) are indicated in white.

Nebraska Natural Resource Commission. Data included elevation, soil types, watershed types, land use, and human population density. Calculations of human population density and land-use impact was based on a $1-\mathrm{km}$ radius surrounding each site. Because minor changes in ecological conditions can affect the size of snails in populations (Clampitt, 1970), snail size data was corrected for geographic location. Data were analyzed using SAS (v. 6.12).

\section{RESULTS}

\section{Cyst distribution}

Sites where at least 1 snail contained a cyst will be referred to as positive sites, whereas sites where none of the 20 snails contained cysts will be referred to as negative sites. Location of sites and the distribution of cysts and status of infection of snails at sites are shown in Figure 1. Thirty-five of the 50 sites were positive (Table I). Of a total of 1,000 snails tested, 395 contained a total of 8,073 cysts (mean intensity $=20.4$; range $=1-465$ ). Mean intensity per site ranged from 1 to 115.2 cysts. The number of cysts per host was highly aggregated among snails (variance-to-mean ratio 2,503:20; Fig. 2). Most hosts harbored 3 or fewer cysts.

Snail size, thus age, correlated significantly but weakly with the number of cysts per infected snail (general linear model, $\mathrm{n}$ $=395 ; P=0.0001 ; R^{2}=0.33$ ), when corrected for geographic location. Snail size did not differ between infected and uninfected hosts (Mann-Whitney $U$-test; $z=0.59$ ).

The presence/absence of cysts at a site (+/- cysts) did not differ with geographic location (i.e., GPS location; Mann-Whitney $U$-test; latitude: $z=-1.19$; longitude: $z=-0.25)$. Thus, 


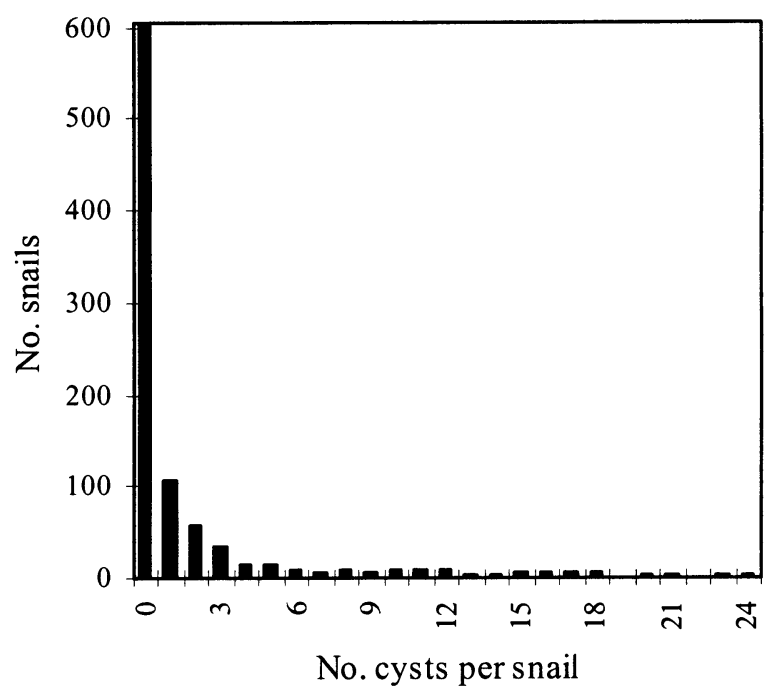

FIGURE 2. Frequency distribution of numbers of cysts per snail. Note that only up to 24 cysts per snail are shown, although 76 more snails were infected with a higher intensity, up to 465 cysts per snail.

sites testing positive were randomly distributed in rural, urban, and suburban localities. Prevalence did not correlate with latitude (regression; $t=1.54$ ) but did significantly correlate with longitude (regression; $\mathrm{n}=35 ; P=0.0003 ; r^{2}=0.27$ ). Further tests revealed that elevation, soil types, or watershed type were not significant factors in these results.

\section{Cyst pathology}

Cysts were found throughout the body of snails (Fig. 3A), but were usually encountered in the mantle, head-foot, and di- gestive gland. No snail IDS reactions were noted around sites of infection (Fig. 3B). Some highly infected snails possessed hundreds of cysts per $3-5 \mathrm{~mm}^{2}$ of flattened snail tissue. The pathology of such high infections was not immediately visible and furthermore, no infected snails were noted to behave abnormally, i.e., movement, retraction of head-foot, etc.

\section{Human disturbances}

Human population density had no significant effect on $+/-$ cysts (Mann-Whitney $U$-test; $z=0.64$ ). Land use was also found to have no significant influence on $+/-$ cysts (logistic regression; $x^{2}=1.79$ ). Additionally, human population density and land use also did not significantly correlate with prevalence (human population density: regression; $t=-0.10$; land use: general linear model; $f=1.05$ ).

\section{DISCUSSION}

A good indicator species for gordiids must meet the following criteria: (1) It must be able to easily become infected with gordiid larvae of various species; (2) it must be widely available; (3) it must be long-lived; (4) it must be relatively sessile; and (5) the host must not be able to mount an IDS reaction to the cysts. The last 2 criteria are especially important, since violation of these could result in false-negative or false-positive results.

The presumed natural hosts for gordiids are aquatic insects, which are infected in water, then carry the cysts to land as adults (Meissner, 1856; Svábeník, 1925; Malakhov and Spiridonov, 1982). However, definitive tests of this hypothesis have never been done for American species of hairworms. Furthermore, aquatic insects would not be acceptable indicator species,
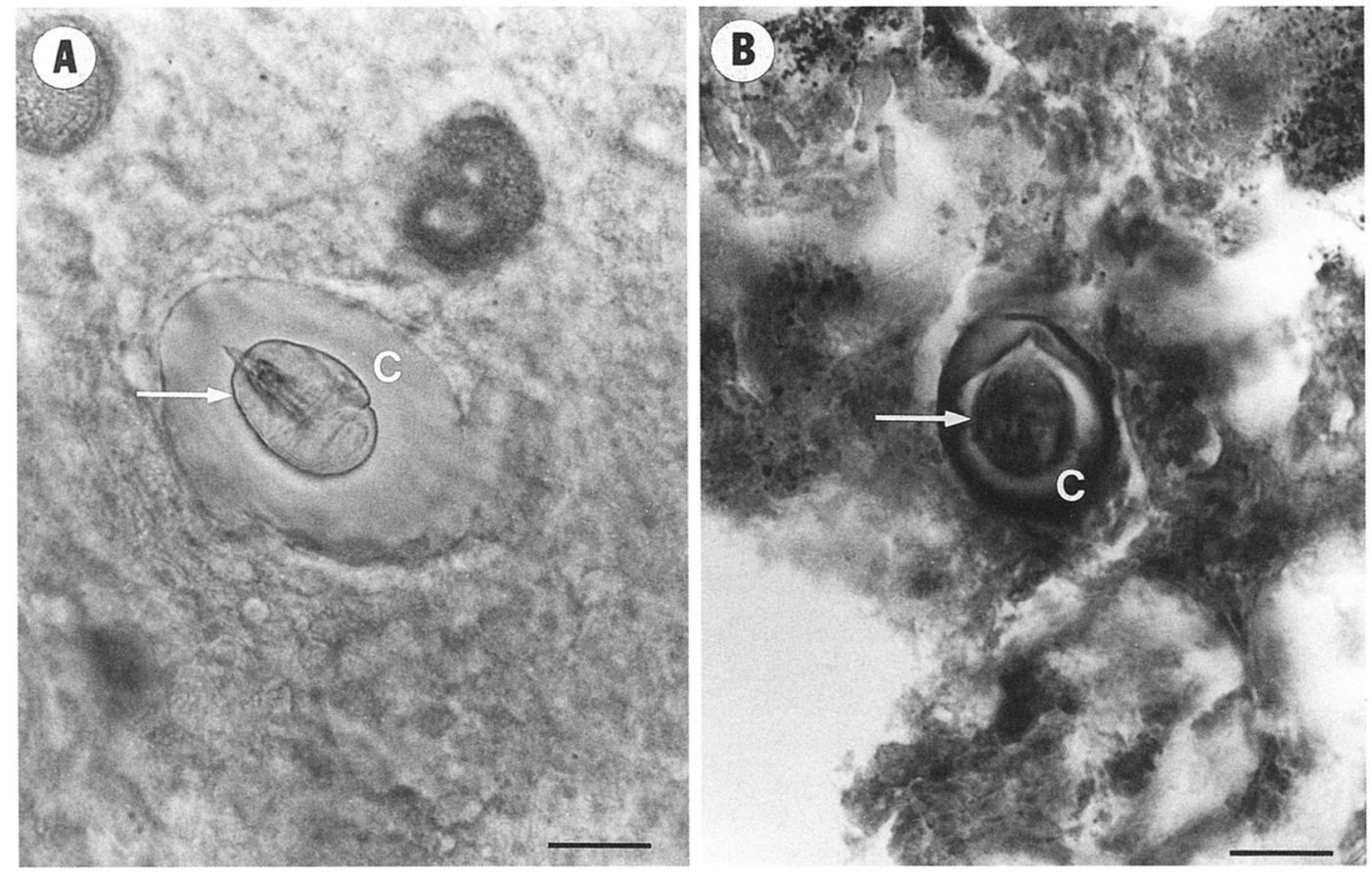

FIGURE 3. Gordiid cysts in tissue of Physa gyrina. An untreated preparation (A) and a histological section of snail tissue (B). Note that in both preparations, but especially the histological section, host encasement of the cyst is not seen. $\mathrm{C}=$ cyst wall; arrow indicates folded larva; scale bars $=15 \mu \mathrm{m}$. 
following the above criteria. First, because of microhabitat restrictions, most aquatic insects are highly limited in their distribution. Second, most aquatic insects are not long-lived. Third, it has been established that some aquatic insects such as mosquitoes can mount a successful melanization reaction to cysts (Poinar and Doelman, 1974). A similar reaction has been noted in Callibaetis sp. (Ephemeroptera: Baetidae) larvae (B. Hanelt, unpubl. data).

As stated above, the involvement of snails in the gordiid life cycle in natural systems is unclear. In the laboratory, infected snails can be used to expose definitive hosts (B. Hanelt, unpubl. data) and are fed easily to starved crickets once removed from their shell. In nature, the aquatic habitat of the snail, its hardened shell, and its retracting defense behavior make snails as a food source for crickets unlikely. However, individual female gordiids produce as many as 4-6 million eggs (Leidy, 1851; Valvassori et al., 1987), possibly infecting hundreds or thousands of snails. Because snails fail to mount an IDS response to cysts and thus cysts likely remain within snail hosts until death, it is possible that at least some of these may be transmitted via snails to the next host. All of these factors combine to make aquatic snails a good gordiid indicator species.

Using the adult stages as indicators for the presence of gordiids, the most recent study on the distribution of gordiids reported 13 sites in Wisconsin, a total of $169,653 \mathrm{~km}^{2}$ (Watermolen and Haen, 1994). The present study, using cysts as indicators, reports 35 sites in $2,238 \mathrm{~km}^{2}$. This result was in spite of finding gordiid adults at only 1 site between 1997 and 2000 within the study area, which highlights the difficulty in detecting adult hairworms, although sites where the life cycle is occurring appear to be common.

Nearly $40 \%$ of $P$. gyrina snails in the study area possessed gordiid cysts. Cysts were overdispersed in the snail population (Fig. 2), a result not uncommon in host-parasite systems (Esch and Fernández, 1993). Other parasites were noted during this study, but none as prevalent as gordiids (data not shown). Additionally, considering only those snails from positive sites, prevalence was $56.4 \%$, making gordiids one of the most prevalent parasites recorded from this snail (Brown et al., 1988; Snyder and Esch, 1993; Sapp and Esch, 1994).

A strong accumulative effect in the number of cysts as snails age was expected, because the chances, or opportunities, or both, for gordiid larvae exposure increase. Although a slightly positive relationship was found, only about a third of the variation in the number of cysts per snail was attributable to snail size. This result was not surprising, because snail age and size are often affected by environmental factors (Clampitt, 1970). Thus, because height is not always a reliable indicator of age, this discrepancy likely influenced the calculation of cyst accumulation.

The correlation between prevalence and longitude, however, was surprising. About a third of the variation in prevalences between sites could be explained by longitude (Fig. 1). Because it is unlikely that longitude alone could have such an influence on prevalence, a third variable was assumed to be responsible for this correlation. However, elevation, soil type, and watershed type were able to be ruled out as contributing factors. Spatial databases on ecosystem type, vegetation, and meteorological data such as amount of rainfall were not available, and thus could not be included in the present analyses. Data on the distribution of natural host populations also were not available. Thus, the reason behind the correlation between longitude and prevalence remains unclear.

The impact of human activities on the distribution of nematomorphs has never been fully investigated. Previous studies have indicated that gordiid populations are affected by landfill leaching (Ehlke, 1979) but not by thermal pollution (SchultzBaker, 1985). The effect of different types of landscape alteration by humans was empirically tested on the distribution of gordiids by use of GIS analysis. Results indicate that gordiids are distributed in nature regardless of the type of human-imposed environmental modification, from environmentally protected properties to farmland and industrial parks. Thus, as urban centers sprawl and grow larger in size per capita resident, humans, and especially their pets, may increasingly encounter gordiids. For example, if the city of Lincoln, Nebraska expanded $5 \mathrm{~km}$ to the northeast, the city boundaries would include one of the most gordiid-prevalent areas of Lancaster county (see Fig. 1).

A limitation to the methodology outlined above is that gordiid species cannot be determined unequivocally from cyst morphology. Although minor variations in morphology were detected, cysts could not be classified by species by looking at the cyst stage within snails. However, subsequent infection experiments can determine the species represented within a sample (Hanelt and Janovy, 1999). Morphometric methods must also be investigated to allow the distinction of gordiid species by the use of morphological characters.

The present study has shown that by simply studying a different life-cycle stage, the perspective of how gordiids are distributed can change tremendously. Using the cyst, gordiid distribution does not appear as ephemeral as on the basis of adults. Rather, gordiids within the study area were common and widely distributed. Since all groups of parasites have unique behaviors, life cycles, and patterns of distribution and abundance, sampling methods must be tailored to each, as has been suggested for free-living organisms (Sutherland, 1996). Thus, during surveys of parasite biodiversity, the use of organismal-specific sampling techniques is critical.

In summary, the above data have 2 broad implications. First, within our study area, the distribution of gordiids is not as discontinuous as suggested by the adults. This finding can likely be extended to larger geographic areas. Gordiids were the most commonly encountered parasites of $P$. gyrina and constitute one of the more common types of metazoan fauna in freshwater streams in Lancaster County. Second, the distribution of gordiids is not affected by human population density or land use, suggesting that these species are resilient to habitat disturbances and may thus be increasingly encountered as cities sprawl. Although the reported survey method will not allow for the calculation of adult worms present at a site, it will allow investigators to readily identify sites at which gordiids occur, thus making the study of this enigmatic group more tractable.

\section{ACKNOWLEDGMENTS}

We gratefully acknowledge Christian G. Elowsky for help with sample collections, Sara V. Brant, and 3 anonymous reviewers for critical comments on this manuscript. This work was supported by a grant from the Initiative for Ecological and Evolutionary Analysis, University of 
Nebraska-Lincoln and by a John F. Davidson memorial fund scholarship.

\section{LITERATURE CITED}

BAYLIS, H. A. 1927. Notes on two gordiids and a mermithid said to have been parasitic in man. Transactions of the Royal Society of Tropical Medicine and Hygiene 21: 203-206.

Brown, K. M., B. K. Leathers, and D. J. Minchella. 1988. Trematode prevalence and the population dynamics of freshwater pond snails. American Midland Naturalist 120: 289-301.

ChANDleR, C. M. 1985. Horsehair worms (Nematomorpha, Gordioidea) from Tennessee, with a review of taxonomy and distribution in the United States. Journal of the Tennessee Academy of Sciences 60: $59-62$.

Chitwood, B. G., AND M. B. Chitwood. 1937. Snails as hosts and carriers of nematodes and Nematomorpha. Nautilus 50: 130-135.

ClampitT, P. T. 1970. Comparative ecology of the snail Physa gyrina and Physa integra (Basommatophora: Physidae). Malacologia 10: $113-151$.

DORIER, A. 1930. Recherches biologiques et systématiques sur les Gordiacés. Annales Université de Grenoble 7: 1-183.

EhLKE, T. A. 1979. Effects of landfill leaching on water quality and biology of a nearby stream, South Cairo, Greene County, New York. Geological Survey, Water-Resources Investigations 22161: 79-113.

EsCh, G. W., AND J. C. FernándeZ. 1993. A functional biology of parasitism: Ecological and evolutionary implications, Chapman \& Hall, London, U.K., 337 p.

HaLl, M. C. 1912. Gordius aquaticus L. as a parasite of man. Science 35: 636.

Hanelt, B., AND J. Janovy, JR. 1999. The life cycle of a horsehair worm, Gordius robustus (Gordioidea: Nematomorpha). Journal of Parasitology 85: 139-141.

Herter, C. D., AND R. E. Neese. 1989. Pseudoparasitism with Gordius robustus. American Family Physician 39: 139-142.

Horton, M. L. 1986. Nonparasitic worm vomited by a dog. Modern Veterinary Practice 67: 905.

INOUE, I. 1960. Studies on the life history of Chordodes japonensis, a species of Gordiacia. II. On the manner of entry into the aquatic insect larvae of Chordodes larvae. Annotationes Zoologicae Japonenses 33: 132-141.

1962. Studies on the life history of Chordodes japonensis, a species of Gordiacea. III. The modes of infection. Annotatiomes Zoologicae Japonenses 35: 12-19.

KAGEI, N. 1977. Discussion on the human parasitism with "hair worms" (Gordioidea: Nematomorpha). Bulletin of the Institute of Public Health 26: 14-18.

LEIDY, J. 1851. On the Gordiacea. Proceedings of the Academy of Sciences, Philadelphia 5: 262-263.

Malakhov, V. V., and S. E. SPIRIDONOv. 1982. Gordionus senkovi, a new species of gordiids (Nematomorpha) and some stages of its embryonic development. Zoologicheskii Zhurnal 61: 810-816.

MeIssner, G. 1856. Beiträge zur Antonomie und Physiologie der Gordiaceen. Zeitschrift Für Wissenschaftliche Zoologie 7: 1-140.

Moisan, P. G., L. S. Mansfield, A. J. Murphy, and A. Hale. 1996. Incidental subcutaneous gordiid parasitism in a cat. Journal of Veterinary Diagnostic Investigation 8: $270-272$.

Poinar, G. O. J., AND J. J. Doelman. 1974. A reexamination of Neochordodes occidentalis (Montg.) comb. $\mathrm{n}$. (Chordodidae: Gordioidea): Larval penetration and defense reaction in Culex pipens $\mathrm{L}$. Journal of Parasitology 60: 327-335.

Pritchard, M. H., and G. O. W. Kruse. 1982. The collection and preservation of animal parasites. University of Nebraska Press, Lincoln, Nebraska, 141 p.

SAPP, K. K., AND G. W. ESCH. 1994. The effects of spatial and temporal heterogeneity as structuring forces for parasite communities in $\mathrm{Hel}$ isoma anceps and Physa gyrina. American Midland Naturalist 132: 91-103.

Schmidt-Rhaesa, A. 1997. Nematomorpha. Gustav Fischer, Stuttgart, Germany, 128 p.

SCHULTZ-BAKER, P. 1985. Macroinvertebrate populations in a thermally impacted reservoir. Transactions of the Illinois State Academy of Sciences 78: $67-80$.

SNYDER, S. D., AND G. W. Esh. 1993. Trematode community structure in the pulmonate snail Physa gyrina. Journal of Parasitology 79: $105-215$.

StILES, C. W. 1907. Three new American cases of infection of man with horse-hair worms (Species Paragordius varius), with summary of all cases reported to date. U.S. Public Health Services Hygiene Laboratory Bulletin 34: 53-68.

SUTHERLAND, W. J. 1996. Ecological census techniques: a handbook. Cambridge University Press, Cambridge, Massachusetts, 336 p.

Svábeník, J. 1925. Parasitismus a metamorfosa druhu Gordius. Publications de la Faculté des Sciences de l'Université Masaryk 58: 148

VALVASSORI, R., G. SCARI, AND G. LANZAVECChIA. 1987. Aspects of morphogenesis in Nematomorphs. Acta embryologiae et morphologiae experimentalis 8: $453-456$.

vON LiNstow, O. 1883. Über die Zwischenwirthe des Gordius aquaticus. Zoologischer Anzeiger 6: 373-374.

WATERMOlEn, D. J., AND G. L. HAEN. 1994. Horsehair worms (phylum Nematomorpha) in Wisconsin, with notes on their occurrence in the Great Lakes. Journal of Great Lakes Research 9: 7-11. 